\title{
内視鏡的点墨法による胃癌の局所リンパ流の検討
}

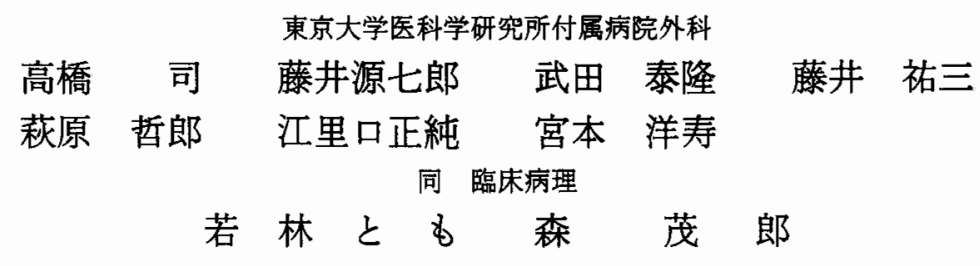

\section{STUDY OF REGIONAL LYMPHATIC PATHWAY IN GASTRIC CANCER BY MEANS OF ENDOSCOPIC INJECTION OF CHINESE INK}

\author{
Tsukasa TAKAHASHI, Genshichiro FUJII, Yasutaka TAKEDA, Yuzo FUJII, \\ Tetsuro HAGIHARA, Masazumi ERIGUCHI and Yôju MIYAMOTo \\ Department of Surgery, Institute of Medical Science Hospital, University of Tokyo
}

\section{Tomo WAKABAYASHI and Shigeo MORI}

Department of Clinical Pathology, Institute of Medical Science Hospital, University of Tokyo

\begin{abstract}
胃癌35症例について経内視鏡的点墨法により胃癌の局所リンパ流について検討した。従来報告され てきた胃の主要リンパ流を認めた他に，厷範用な癌の広がりを持つ症例では，噴門部近傍に点墨して もほぼ全域のリンパ節に墨汁の取り込みが認められた。 また小弯リンパ節に癌転移を認めた例では 6 例中 2 例に, 大弯リンパ節右群あるいは幽門下リンパ節に癌転移を認めた 3 例のうち 2 例に局所リン パ流遮断によると思われる異常リンパ流を認めた。一方, 左胃動脈幹リンパ節, 総肝動脈幹リンパ節, 脾動脈幹リンパ節には，45\%,64\%, 45\%と高率に墨汁の取り込みが認められ，胃の 1 次りンパ節とし て胃癌の手術に際し，十分に郭清する必要があると考觉られた。
\end{abstract}

臬引用語：胃癌の局所リンパ流, 胃癌リンバ節転移, 䅅内視鏡的点墨法

はじめに

胃癌根治手術に扔いては主病巣の完全除去ととも に, 胃所属リンパ系の一括除去が必要であることは言 らまでもない，胃リンパ系の研究は古くから行われ， 系統的解剖学による研究がその主体をなしていたが,

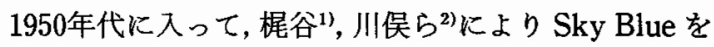
用いての生体染色が行われ，生体下に打ける担癌状態 での胃のリンパ流が研究されるよ5になった。われわ れは胃所属リンパ節を経内視鏡的に点墨法を用いて染 色し, 術後摘出標本リンパ節の mapping を作製し, 病 理組織学的にリンパ節への墨汁の取り込みを検索して 胃癌に怙ける局所リンパ流について再検討した。 その 目的は胃癌手術時におけるリンパ節郭清をより效果的

$<1985$ 年11月12日受理 $>$ 別刷請求先：高橋 司 T108 港区白金台 4-6-1 東京大学医科学研究 所外科
に遂行すること, 術後の残存リンパ節を対象に局所的 に免疫倵活剤を投与しより効果的な補助的免疫療法を 行らに際し，その基礎となる知見をえることにある。 対象および方法

対象とした症例は1982年 1 月より1983年 6 月までの 当院外科で行われた胃癌手術症例のうち, 治瘾切除を 行いえた 35 症例である. 内訳は早期胃癌18例, 進行胃 癌17例であり男女比は 2 対 1 であった。

方法はOlympus GF-B $\mathrm{B}_{3}$ 内視鏡と注射用 Olympus $\mathrm{MN}-3 \mathrm{~K}$ 針を用い, 術前24 48時間に, 胃の粘膜下層に 墨汁を注射した。墨汁は市販されているもので加压隇 菌して使用した. 表 1 に示したように，局所ッンパ流 の方向を明確にするため点墨部位は 1 力所とし, 点墨 量を0.1 0.2ml と少量とした. 点墨は原則として畽晹 の近傍としたが,その流れを分類しやすくするために， 噴門部近傍 5 例, 胃角部小弯20例, 胃幽門部大弯 10 例 
表 1

\begin{tabular}{|c|c|c|}
\hline 点墨部位 & 㱏例数 & 雸船占居部位 \\
\hline 噴 門 部 直下 & 5 & $\mathrm{C}, \mathrm{CM}$ \\
\hline 胃角部小弯側 & 20 & $\mathrm{AM}, \mathrm{MA}$ \\
\hline 胃幽門部大驾側 & 10 & A \\
\hline
\end{tabular}

図 1 実物標本拉よびシェーマー
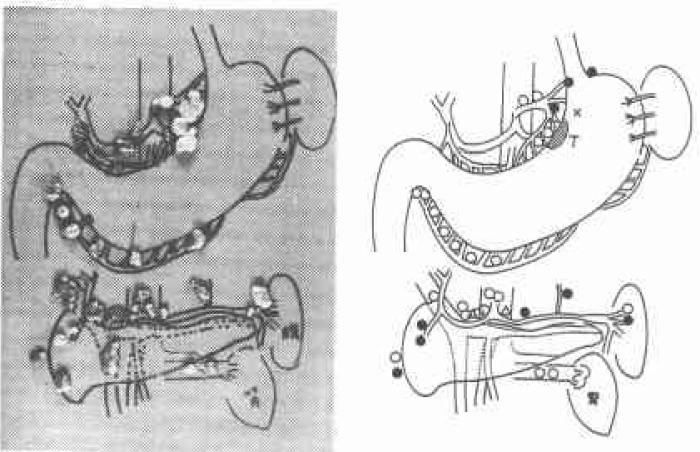

$x$ : 点墨部位, : 墨汁摄取リンパ節, $\bigcirc$ : 非墨汁 摄取リンパ節, $\Delta:$ 癌転移リンパ節

表 2

\begin{tabular}{|c|c|}
\hline 総 & 1074ケ \\
\hline 1 症 例 平均 リンパ 節 数 & 34 ヶ \\
\hline 墨汁を取り込んだリンパ節数 & 331 ヶ $(30.8 \%)$ \\
\hline 転 移 リ V ～八 節 数 & 104ל (9.6\%) \\
\hline 転移リンパ節の墨汁を取り込んだ数 & 30 r $(28.9 \%)$ \\
\hline
\end{tabular}

に行った.術後摘出標本からリンパ節をすべて摘出し， それらの大きさ, 肉眼的癌転移の有無, 肉眼的墨汁の 取り込みの有無を観察した。摘出リンパ節は 1 個ずつ 摽本番号をつけ，「胃癌取り扱い規約 ${ }^{3)} 」 に$ 準じて分類 し, 図 1 のように mapping した。ささらに病理組織学的 にリンパ節転移の有無とリンパ節の墨汁の取り込みの 有無を検索し，胃の局所リンパ流を解析しリンパ節転 移々の関倸についても検討した。今回，われわれが検 索したリンパ節総数は1,074個であり,詳紐は表 2 のご とくである.

\section{結果}

1）噴門部近傍に点墨した場合

主な経路は図 2 のように，左胃動脈噴門枝と胃体上 部小弯側の胃壁枝に沿らリンパ節から左胃動脈幹リン パ節に至り，腹腔動脈周囲リンパ節に入るもので 5 例 中全例に認められた。ささらに図3のように上記の主要
因2 噴門部近傍に点墨した場合の主なりンバ流

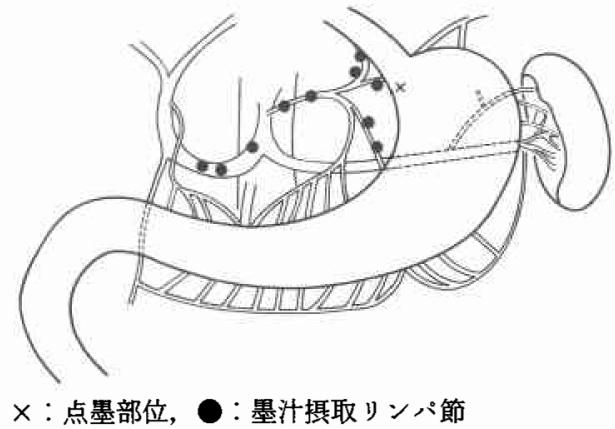

図 3 後胃動脈から脾動脈幹リンパ節に至るリンパ流

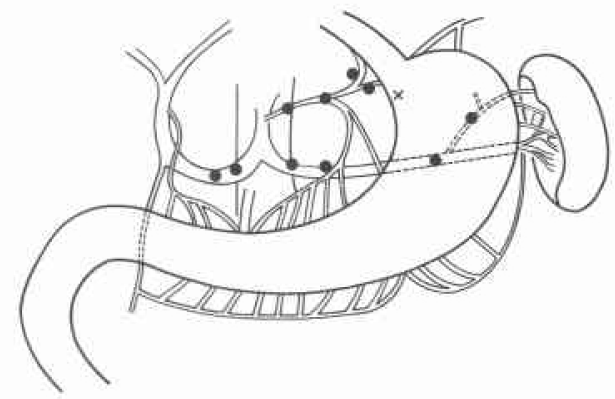

$\times$ : 点墨部位, $:$ 墨汁摄取リンパ節

図 4 広範囲な広がりを有する胃癌症例に持けるリン 八流

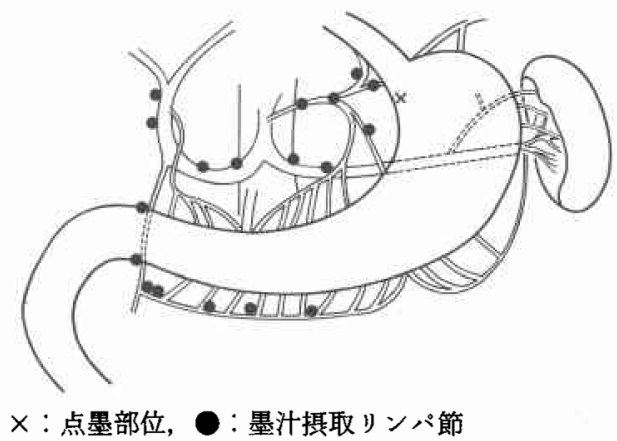

径路のほかに胃体部後壁の後胃動脈に沿って, 脾動脈 幹リンパ節に至り，腹腔動脈周囲リンパ節に入るもの が 5 例中 3 例に認められた。 図 4 は広範囲な癌の広が り（たとえばCMA）を示した 2 症例の墨汁の取り込み を示したもので, 主要径路の他に, 大弯リンパ節右群, 脺後部リンバ節, 肝十二指腸間膜内リンパ節に畦汁の 取り込みが認められ，リンパ流の広範囲な広がりが観 察された。 また，図2４ 4に示されるように，噴門部 
表 3 噴門部近傍に点墨した場合 $(n=5)$

\begin{tabular}{|c|c|c|c|c|c|}
\hline 群別 & $\begin{array}{l}\text { リンパ節 } \\
\text { 番号 }\end{array}$ & リンバ節数 & $\begin{array}{c}\text { 墨汁を取り込んた } \\
\text { リソパ節数 }\end{array}$ & $\begin{array}{c}\text { 墨汁撕取リンパ節率 } \\
(\%)\end{array}$ & $\begin{array}{l}\text { リン八擳群 } \\
\text { 墨汁攝取率 } \\
(\%)\end{array}$ \\
\hline \multirow{6}{*}{$\mathrm{n}_{1}$} & 1 & 35 & 17 & 49 & \multirow{6}{*}{$\begin{array}{l}35 / 89 \\
=39 \%\end{array}$} \\
\hline & 2 & 0 & 0 & 0 & \\
\hline & ${ }^{*} 3 \mathrm{~s}$ & 46 & 17 & 37 & \\
\hline & $* * 3 d$ & 0 & 0 & 0 & \\
\hline & $4 \mathrm{sb}$ & 2 & 1 & 50 & \\
\hline & $4 \mathrm{sa}$ & 6 & 0 & 0 & \\
\hline \multirow{8}{*}{$\mathrm{n}_{2}$} & $4 d$ & 37 & 3 & 8 & \multirow{8}{*}{$\begin{array}{l}59 / 134 \\
=44 \%\end{array}$} \\
\hline & 5 & 7 & 5 & 71 & \\
\hline & 6 & 25 & 7 & 28 & \\
\hline & 7 & 17 & 8 & 47 & \\
\hline & 8 & 26 & 20 & 77 & \\
\hline & 9 & 1 & 0 & 0 & \\
\hline & 10 & 7 & 2 & 29 & \\
\hline & 11 & 14 & 11 & 78 & \\
\hline \multirow{2}{*}{$\mathrm{n}_{3}$} & 12 & 7 & 7 & 100 & $12 / 12$ \\
\hline & 13 & 5 & 5 & 100 & $=100 \%$ \\
\hline
\end{tabular}

*3s：小杩リンパ節（左胃動脈領域）

**3d：小弯リンパ節(右胃動脈領域)

因 5 胃角部小弯に点墨した場合の主なリンパ流

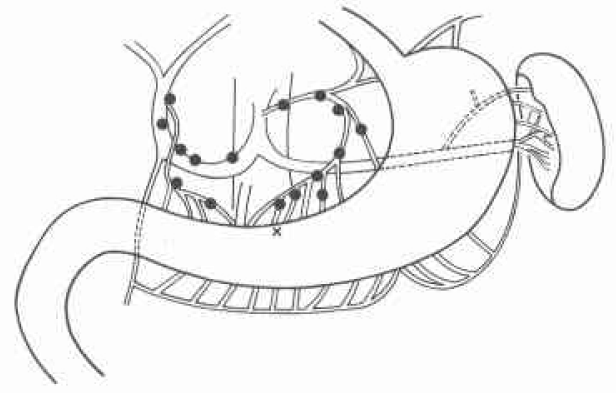

$x$ : 点墨部位, @ : 墨汁撖取リンパ節

因 6 肝十二指腸間膜内リンパ節へ至るリンパ流

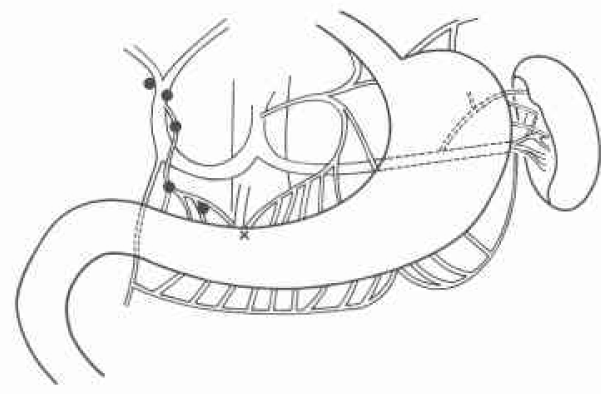

$\times$ : 点墨部位,
近傍に点墨しても, 総肝動脈幹リンパ節で墨汁の取り 込みが認められた。

これらの症例で，C, CM 領域癌に準じてリンパ節を 群別し, 各リンパ節群に和ける墨汁の取り达及率につ いて調べてみた。表了のように，1群リンパ節である 右噴門リンパ節，および小弯リンパ節へは $49 \% ， 37 \%$ の墨汁の取り込みが認められ，2 群リンパ節である左 胃動脈幹リンパ節，総肝動脈幹リンパ節，脾動脈幹リ ンパ節には， $47 \% ， 77 \% ， 78 \%$ と高率な墨汁の取り込 みが認められた。 3 群リンパ節は摘出リンパ節数が少 ないため，非常に高率となったが，このリンバ節は広 範囲な癌の広がりを有した 2 症例におけるもので, こ の 2 症例では，注ほ全域のリンパ節に墨汁の取り込み を認めた。

2）胃角部小弯に点墨した場合

主要径路は，図5のように小弯リンパ節から左胃動 脈幹リンパ節怙よび幽門上リンパ節から総肝動脈幹リ ンパ節へ入って，腹腔動脈周囲リンパ節へ至るもので あった.しかし図6のように主要径路をとりながらも， 幽門上リンパ節から肝十二指腸間膜内リンパ節へ至る ものが20例中 6 例に認められた。 また図 7 のように主 要径路をとりながら，小弯リンパ節から上行して，右 噴門リンパ節に墨汁の取り込みを認めた症例が20例中 
図 7 右嘪門リンパ節へ至るリンパ流

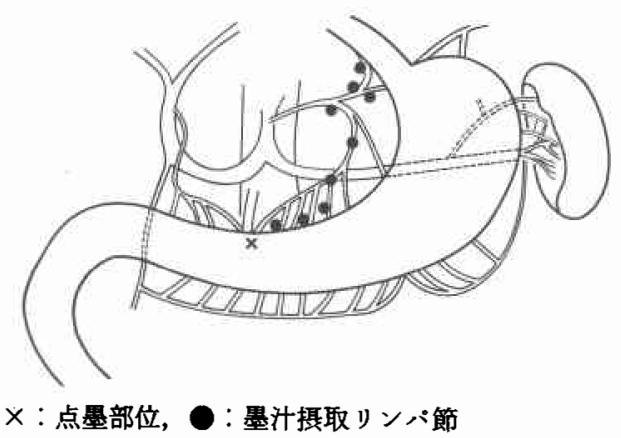

図 8 小弯リンパ節に癌転移を有した場合のリンパ流

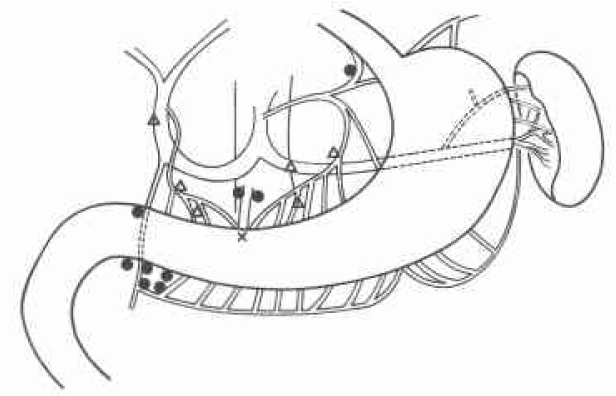

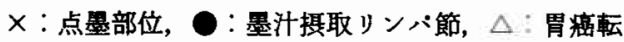
移リンパ節
7 例に認められた。胃小弯リンパ節に癌転移を多く有 する症例では，図 8 のように幽門下リンパ節，さらに は, 荤後部リンパ節や腸間膜根部リンパ節へ墨汁の取 り込みが 6 例中 2 例に認められた。

これらの症例で MA, M, MC 領域癌に準じてりンパ 節を群別し各リンパ節群の墨汁の取り込み率について 検討してみた，表 4 のように 1 群リンパ節である小弯 リンパ節には37.5\%の墨汁の取り込みが認められ，右 噴門リンパ節，幽門上リンパ節にもそれぞれ37.5\%, $41.2 \%$ 取り込みを認めた，2群リンパ節である左胃 動脈幹リンパ節, 総肝動脈幹リンパ節, 脾門リンパ節 では，52.5\%，48.3\%，30.8\%の墨汁の取り込みが認 められた。 3 群リンパ節は郭清リンパ節数が少ないた め, 同様には比較できないが，胃角部小弯に点墨した 場合には，各群におけるリンパ節の畦汁の取り込みは 比較的均一な広がりを認めた。

3）胃幽門部大弯に点墨した場合

主要径路は図 9 のごとく，大弯リンパ節右群から幽 門下リンパ節に入り，幽門後側を胃十二指腸動脈に 沿って総肝動脈幹リンパ節へ至るものと, 腪頭表面を 介して直接脾動脈幹リンパ節, 左胃動脈幹リンパ節へ 至り, 腹腔動脈周囲リンパ節へ至る のので10例中 7 例

表 4 胃角部に点墨した場合 $(n=20)$

\begin{tabular}{|c|c|c|c|c|c|}
\hline 群別 & $\begin{array}{l}\text { リンバ節 } \\
\text { 番号 }\end{array}$ & リンパ節数 & $\begin{array}{c}\text { 墨汁を取り込んた } \\
\text { リソパ節数 }\end{array}$ & $\begin{array}{c}\text { 墨计摂取りンパ節率 } \\
(\%)\end{array}$ & $\begin{array}{c}\text { リソパ節群 } \\
\text { 墨汁摄取率 } \\
(\%)\end{array}$ \\
\hline \multirow{8}{*}{$\mathrm{n}_{1}$} & 1 & 40 & 15 & 37.5 & \multirow{8}{*}{$\begin{array}{l}81 / 370 \\
=22 \%\end{array}$} \\
\hline & $* 3 \mathrm{~s}$ & 104 & 39 & 37.5 & \\
\hline & $* * 3 d$ & 8 & 3 & 37.5 & \\
\hline & $4 d$ & 107 & 4 & 3.7 & \\
\hline & $4 \mathrm{sb}$ & 16 & 0 & 0 & \\
\hline & $4 \mathrm{sa}$ & 6 & 0 & 0 & \\
\hline & 5 & 17 & 7 & 41.2 & \\
\hline & 6 & 72 & 13 & 18 & \\
\hline \multirow{6}{*}{$\mathrm{n}_{2}$} & 2 & 4 & 2 & 50 & \multirow{6}{*}{$\begin{array}{l}58 / 133 \\
=44 \%\end{array}$} \\
\hline & 7 & 40 & 21 & 52.5 & \\
\hline & 8 & 58 & 28 & 48.3 & \\
\hline & 9 & 8 & 2 & 25 & \\
\hline & 10 & 13 & 4 & 30.8 & \\
\hline & 11 & 10 & 1 & 10 & \\
\hline \multirow{4}{*}{$\mathbf{n}_{3}$} & 12 & 10 & 6 & 60 & \multirow{4}{*}{$\begin{array}{l}12 / 29 \\
=42 \%\end{array}$} \\
\hline & 13 & 12 & 4 & 33.3 & \\
\hline & 14 & 6 & 2 & 12.5 & \\
\hline & 16 & 1 & 0 & 0 & \\
\hline
\end{tabular}

*3s：小弯リンパ節(左胃動脈領域)

**3d：小弯yンパ節(右胃動脈領域) 
図 9 胃幽門部大弯に点墨した場合の主なリンパ流

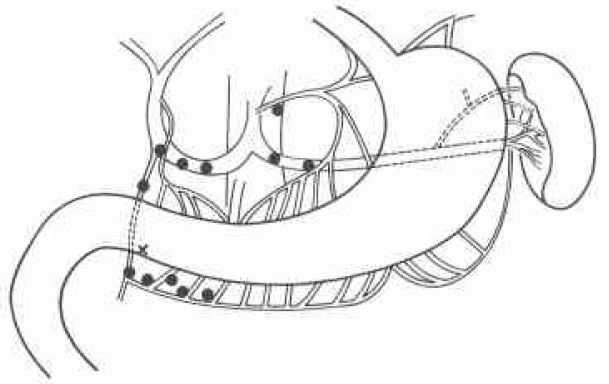

$\times$ : 点墨部位,

墨汁摄取リンパ節

図10 肝十二指腸間膜内右㑡リンパ節に至るリンパ流

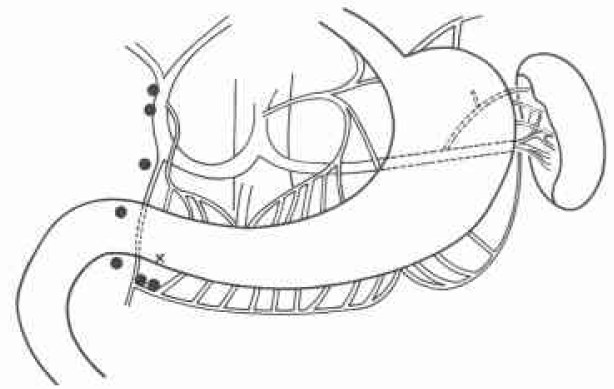

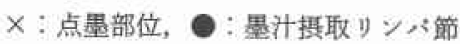

図11 大弯リンパ節右群あるいは幽門下リンパ節に癌 転移を有した場合のリンパ流

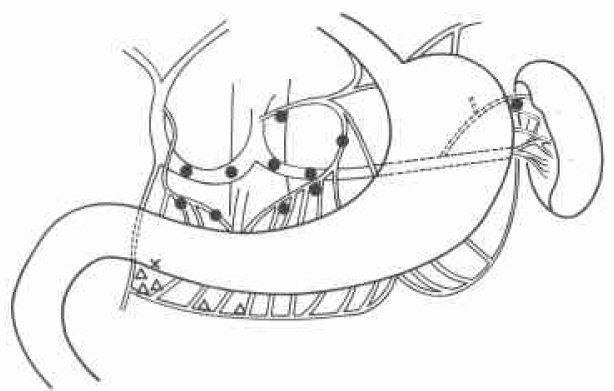

$\times$ : 点墨部位,

移りンパ節

に認められた。 また，図10のよらに主要径路をとりな がら幽門下リンパ節から荤後部リンパ節へ至り, 肝十 二指腸間膜内右側リンパ節に墨汁の取り込みを認めた 症例が 7 例中 2 例に認められた，大弯リンパ節右群あ るいは幽門下リンパ節に癌転移を有する 3 症例の5 ち，2 例では，図11のよ5に小弯リンパ節，総肝動脈 幹リンパ節, 脾動脈幹リンパ節への墨汁の取り込みが 認められ，幽門下リンパ節への墨汁の取り込みはな かった.

これらの症例で $\mathrm{A}, \mathrm{AM}$ 領域癌に準じてリンパ節を

表 5 幽門側大弯部に点墨した場合 $(\mathrm{n}=10)$

\begin{tabular}{|c|c|c|c|c|c|}
\hline 類別 & $\begin{array}{l}\text { リンパ節 } \\
\text { 番号 }\end{array}$ & リンバ節数 & $\begin{array}{c}\text { 墨汁を取り迅んた } \\
\text { リンパ節数 }\end{array}$ & $\begin{array}{c}\text { 眰汁摂取りンパ節率 } \\
(\%)\end{array}$ & $\begin{array}{c}\text { yンパ節群 } \\
\text { 墨汁攝取率 } \\
\text { (\%) }\end{array}$ \\
\hline \multirow{7}{*}{$\mathrm{n}_{1}$} & $* 3 s$ & 73 & 8 & 11 & \multirow{7}{*}{$\begin{array}{l}40 / 233 \\
=17 \%\end{array}$} \\
\hline & $* * 3 d$ & 5 & 1 & 20 & \\
\hline & $4 d$ & 82 & 12 & 15 & \\
\hline & $4 \mathrm{sb}$ & 18 & 0 & 0 & \\
\hline & $4 \mathrm{sa}$ & 4 & 1 & 25 & \\
\hline & 5 & 4 & 1 & 25 & \\
\hline & 6 & 47 & 17 & 36 & \\
\hline \multirow{4}{*}{$\mathrm{n}_{2}$} & 1 & 25 & 7 & 28 & \multirow{4}{*}{$\begin{array}{l}42 / 91 \\
=46 \%\end{array}$} \\
\hline & 7 & 28 & 10 & 36 & \\
\hline & 8 & 38 & 25 & 66 & \\
\hline & 9 & 0 & 0 & 0 & \\
\hline \multirow{5}{*}{$\mathrm{n}_{3}$} & 2 & 2 & 1 & 50 & \multirow{5}{*}{$\begin{array}{l}17 / 26 \\
=65 \%\end{array}$} \\
\hline & 10 & 1 & 1 & 100 & \\
\hline & 11 & 13 & 6 & 46 & \\
\hline & 12 & 5 & 4 & 80 & \\
\hline & 13 & 5 & 5 & 100 & \\
\hline
\end{tabular}

*3s：小弯リンバ節(左胃動脈領域)

**3d：小弯リンパ節(右胃動脈領域) 
群別し各リンパ節群の墨汁の取り込み率について検討 した。表 5 のよらに 1 群リンパ節である大弯リンパ節 右群，幽門下リンパ節へは $15 \% ， 36 \%$ の取り込みが認 められた。 2 群リンパ節である左胃動脈幹リンパ節, 総肝動脈幹リンパ節の墨汁の取り込み率は $36 \%, 66 \%$ と比較的高率であった， 3 群りンパ節は郭清リンパ節 数が少ないが，各りンパ節に括ける墨汁の取り込及率 は高く, 脾動脈幹リンパ節で $46 \%$, 肝十二指腸間膜内 リンパ節, 荤後部リンパ節では, $80 \%, 100 \%$ と高い墨 汁の取り込みが認められた。

\section{考 察}

ヒト胃リンパ系の研究は古くから行われ, 1930年代, 松本 ${ }^{4)}$ ，井上ら ${ }^{5)}$ はゲロタ氏液などを用い，主として動 物, 屍体，および胎児屍体について詳細な系統的研究 を報告した。1939年，MacMaster and Persons ${ }^{6}$ は水 溶性色素 Pontamine Sky Blue を用いてリンパ組織を 染色し動物実験に使用した。さらに1950年には Weinberg ${ }^{788)}$ はこの色素を胃癌, 肺癌の手術に応用し， 所属リンパ節を染色してリンパ節郭清を行った。かが 国に㧊いても，梶谷と山田"が1954年，胃癌，乳癌の手 術の際 Direct Sky Blue（友田）を使用して, リンパ 組織の郭清に大いに有益であると報告した。 また, 1956 年川俣ら ${ }^{2)}$ 同様の色素を用いて開腹時，胃壁に色素 を注入し，正常胃壁における胃リンパ流と胃癌におけ るリンパ走行の異常を報告した。その後1960年代後半

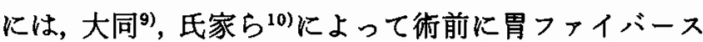
コープを用いて水溶性色素および墨汁を胃粘膜下層に 注入して胃壁内リンパ流について検討するととるに， 術中染色されたリンパ節についての観察が報告され た. 1970年に入って, 打田 ${ }^{11}$, 丸山ら ${ }^{12}$ により油性造影 剂を用いての Lymphographyによる検討がなされ，

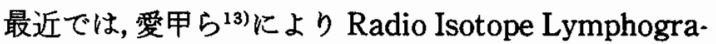
phyによるリンパ流の検討がなされるよらになった。

われわれは胃癌の局所リンパ流を知る上で, 経内視 鏡的に所属リンパ節を染色することがより病態生理的 に胃のリンパ流を検索する方法ではないかと考兄, 点 墨法を用いて検討した。

水溶珄色素は安心して使用できるが，速やかに流れ 去り，時間が経過すると染色されたリンパ節の色が消 学ること，また術後の組織学的検索にむかない欠点が ある。一方墨汁は術前内視鏡を用いて胃粘膜下に注入 しても副作用がなく，長時間に及んで所属リンパ節が 染色され術後の組織学的検索も十分に行劣る利点があ る。
墨汁の生体に与える影響について,小島ら ${ }^{14)}$ は, マウ スでは墨汁を $24 \mathrm{mg} / 100 \mathrm{~g}$ ，ラットでは $10 \mathrm{mg} / 100 \mathrm{~g}$ 使用 できると述べており，大同9)，氏家 ${ }^{10)}$ ，石榑ら ${ }^{15)}$ 臨床 的に用いて特に副作用を認めなかったと報告してい る.われわれが今回注入した墨汁の量は $0.2 \mathrm{ml} て ゙ 0.1$ $\mathrm{mg} / \mathrm{kg}$ 以下であり, 大部分の墨汁は切除標本に含まれ ており副作用についてはほとんど考虑する必要がない と考元られた。実䟢35症例に用いて, 術前, 術後の検 查データーでも特に異常を認めず，患者の自他覚症状 でも特に異常はなかった。

墨汁を注入してからどの程度の時間を経れば所属り ンパ節が染色されるかということについて，大同ら は48時間以上を要すると述べているが，石榑 ${ }^{15}$ は墨汁 注入後数 10 分で第 2 次リンパ節まで達したと報告して いる.そこでわれわれは今回術前24４8時間前に点畦 を行った。

胃噴門部のリンパ流について, 山田 ${ }^{16)}$ は左胃動脈系, 左下横隔膜動脈系，下食道固有動脈に沿らリンパ系の 3 径路があり，噴門部右側左側ともに左胃動脈系を主 とすると報告している．また丸山ら ${ }^{12)}$ は経内視鏡的に リピオドールを注入して噴門胃体上部のリンパ流につ いて検討し, Ascending flow, right side flow, left side flow の 3 径路に分類している. われわれは噴門部近傍 に点量した 5 症例に括いて全例に左胃動脈系リンパ節

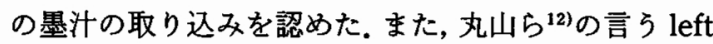
side flow のらち後胃動脈に沿って脾動脈に合流する 後胃ルートと考えられる墨汁の取り込みを示す症例が $60 \%$ に認められた。 この後胃動脈に関しては, 井上 ${ }^{5} の$ 報告に記載があり，川路 ${ }^{17}$ 多胃上部後壁に色素を注入 すると後胃動脈に沿らリンパ流のあることを報告して いる．噴門近傍に点墨した場合，総肝動脈幹リンパ節 に墨汁の取り込みを認めたかどらか記載された文献は あまりみないが，われわれは77\%と高率な畦汁の取り 込みを認めた。このことは同部位のリンパ流が豊富な ことを示して括り，胃癌手術の郭清時に十分注意を要 するものと考えられた。 また, CMA のような広範囲な 広がりを持つ 2 症例では，ほぼ全域のリンパ節に墨汁 の取り込みが認められたことは興味深い．この 2 症例 は癌深達度 $\mathrm{m}$, および ssr の症例で, 深達度mの症例で は小弯リンパ節に 1 個転移を認めただけだが，郭清リ ンパ節40個のうち20個のリンパ節に墨汁が取り込まれ ており，そのリンパ節番号はNo. $1,3,4 \mathrm{~d}, 5,6,7,8$, 10，11，12，13に及んだ。一方深達度 ssr の症例では郭 清リンパ節49個のうち19個のリンパ節に墨汁が取り込 
まれて招り，そのリンパ節番号はNo. 1, 3, 4d, 4sb, 5,

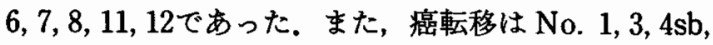
$5,6,7,8,10,11,12$ に認められた。このように広範囲な 広がりを持つ胃癌症例では胃壁内のリンパ流に破綻が 生じていると考兄られ，点畦法によって十分にリンパ 節の染色される範囲を知ることはリンパ節郭清には有 用であると考えられた。

胃角部小弯のリンパ流について検討してみると, 従 来の報告どおり，われわれは主要径路として小弯リン パ節から左胃動脈幹リンパ節怙よび幽門上リンパ節を へて総肝動脈幹リンパ節に至り, 腹腔動脈周囲リンパ 節へ至る径路を認めた。 また, われわれは山田 ${ }^{16)}$, 川俣 $ら^{2)}$ と同様に肝固有動脈に沿って上行し肝十二指腸間 膜内リンパ節を染色した症例を $30 \%$ に認めた。 山田 ${ }^{16)}$ は小弯を上行する色素は噴門または，右噴門リンパ節 に達することはないとしているが，川俣2)は小弯を上 行し, さらに食道へ向らリンパ流を認めたと報告して いる.われわれも川俣ら ${ }^{2)}$ と同様に右噴門リンパ節へ の墨汁の取り込みを $35 \%$ の症例に認めた。 また胃全摘 を行った 4 症例のうち 2 症例に脾門リンパ節への墨汁 の取り込みを認めた。弯りンパ節に癌転移を有する 6 症例のうち 2 症例では, 主要径路をとらずに 1 例は 幽門下リンパ節にのみ畦汁の取り込みを認め，も51 例では幽門下リンパ節，䐙後部リンパ節，腸間膜根部 リンパ節，および右噴門リンパ節に墨汁の取り込みが 認められた。このように小弯りンパ節に癌転移を有す る症例の中には, 小弯リンパ流の遮断による迂回を示 唆するものがあり，かかる症例に抢ける胃癌リンパ節 郭清手術時に点墨法により異常リンパ流を知ることは 有用であると考古られた。

胃幽門部大弯におけるリンパ流について, 山田 ${ }^{16)}$ は, 右胃大網動脈に沿って幽門下リンパ節に至り，これを へて, (A); 满十二指腸動脈に沿って総肝動脈幹リンパ 節に至る径路，B；荤頭表面を介して右または左腹腔 リンパ節へ至る径路, (C) ; 下苹十二指腸動脈に沿って 腸間膜根部リンパ節へ至る径路の 3 径路があると報告 している. 井上5)は(A)の径路はむしろ例外的であると 報告しているが，山田 ${ }^{16)}$ は(A), (B), (C)の径路の出現率は $6: 12: 13$ であるとし，(A), (B), (C)の中で 2 径路を共有 するるのは23例中16例であったと報告している，今回 われわれの検索では, 山田 ${ }^{16)}$ の言う(A), (B)の径路を共有 したと考えられるすのが10例中 7 例に認められた。さ らに幽門下リンパ節から荤後部リンパ節へ至り肝十二 指腸間膜内リンパ節に墨汁の取り込みを認めた症例が
2 例あった。この径路について山田 ${ }^{16)} 1$ 例認めたと 報告している。一方大弯リンパ節右群あるいは幽門下 リンパ節に癌転移を認めた 3 症例のうち, 小弯リンパ 節, 総肝動脈幹リンパ節, 短胃動脈に沿らリンパ節に のみ墨汁の取り込みを認めたものが 1 例，小弯リンパ 節，脾動脈幹リンパ節にのみ墨汁の取り込みを認めた ものが 1 例あった。これら 2 症例では明らかに幽門下 リンパ節へ至るリンパ流が遮断されることによる迂回 路が示され，かかる症例に拈ける異常りンパ流を知る 上で, 点墨法は有用であると考兄られた。 山田 ${ }^{16)}$ は幽門 下リンパ節の輸出管は橧頭と密接に関係し，幽門下リ ンパ節に癌転移を有する胃癌の処置について十分注意 を要すると報告しており，今後さらに同部位のリンパ 流について検索を要するるのと考觉られた.

忽那18) ${ }^{18}$ 胃上部癌の場合, 脾動脈幹リンパ節は当然 1 次リンパ節飞，また胃下部癌の場合総肝動脈幹リン バ節は 1 次リンパ節へ入れるべきとしている. 現在の 「胃癌取り扱い規約」3)をてる，1，2，3 群リンパ節 は，いわゆる胃の $1 ， 2 ， 3$ 次リンパ節とは異なるもの であることを明記している．今回われわれの行った点 墨法で 1 群から 3 群までのリンパ節の墨汁の取り込及 をみてみると, 左胃動脈幹リンパ節, 総肝動脈幹リン パ節, 脾動脈幹リンパ節には高率に墨汁の取り込みが 認められ，これらリンバ節への豊富なリンパ流が示唆 された。同時にこれらリンパ節がいわゆる胃の 1 次リ ンパ節として胃癌手術の際，十分に郭清されるべきも のと考兄られた。むた脾門りンパ節や苏後部リンパ節, 肝十二指腸間膜内リンパ節にも高率に墨汁の取り込み が認められ，現在行われている「胃癌取り扱い規約」3) の $\mathrm{R}_{2}$ の胃亜全摘術では必須となっていないこれらの リンパ節に対しても十分な注意をはらら必要があると 考学られた，郭清が十分にできにくいこれらのリンパ 節を対象に局所的に術中に非特異的免疫賦活剤を投与 することや，術前あるいは術後にも経内視鏡的にこれ らリンパ節を刺激することが胃癌術後のリンパ節転移 に対し有用であるうことが示唆された。

\section{おわりに}

胃癌35例について経内視鏡的点墨法により胃癌の局 所リンパ流について検討した。従来報告されてきた胃 の主要リンパ流を認めたほかに，広範囲な癌の広がり を持つ症例では，噴門部近傍に点墨してもほぼ全域の リンパ節に墨汁の取り込みが認められた。またリンパ 節転移を多く有する症例では，局所りンパ流遮断によ ると思われる迁回を示す異常リンパ流が認められた。 
一方, 左胃動脈幹リンパ節, 総肝動脈幹リンパ節, 脾 動脈幹リンパ節には高率に墨汁の取り込みが認めら れ, 胃の 1 次リンパ節として胃癌手術の際, 十分に郭 清する必要があると考えられた。

稿を終るに臨み, 御指導御校閲を賜った癌研付属病院, 外 科副部長高木国夫先生に深謝いたします。

本論文の要旨は第24回日本消化器外科学会総会 (京都)に おいて発表した。

\section{文 献}

1）棍谷 銀，山田 肃: Sky Bluekよるッンバ采統 染出しの癌根治手術への応用。癌の臨 1 ： $513-516,1955$

2) 川俣健二, 新島 佐：胃癌のリンパ腺転移に関す 了研究. 癌の臨 $2: 196-203,1956$

3）胃癌研究会編：外科・病理. 胃澏取扱い規約. 東京, 金原出版, 1979

4）松本㣢治：廻盲部及ビ胃淋巴管系，研究. 医研究 $7: 917-1102,1933$

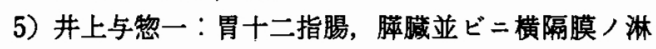
巴管系統. 解剖誌 9:35-115，1936

6) MacMaster PD, Parsons RJ : Physiological conditions existing in connective tissue: Method of interstitical spread of vital dyes. J Exp Med 69:247-264, 1939

7) Weinberg J, Greaney EM: Identification of regional lymph nodes by means of avital stain. ing dye during surgery of gastric cancer. Surg Gynecol Obstet 90:561-567, 1950
8) Weinberg JA: Identification of regional lymph nodes in treatment of bronchiogenic carcinoma. J Thorac Surg $22: 517-526,1951$

9）大同礼次郎, 鹿野 実, 広谷謙一济：経温的色素 注入によるリンパ節染色法について。手術 21 : 799-804, 1967

10）系家 忠,三国主税, 井林 淳はか：ファイバース コープによる直視下胃壁内注射に関する研究。胃 と腸 5:725-732，1970

11）打田日出夫：胃及び周辺臟器リンバ系造影関す る研究. 日医放線会誌 $31: 259-285,1971$

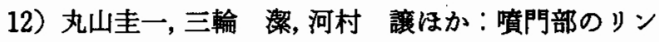
ハ流と癌の転移一Lymphographyによる検討一. 胃之腸 $13 ： 1535-1542 ， 1978$

13）委甲 孝, 才原哲吏, 西 满正：噴門部のリンパ流 と噴門部癌のリンパ節転移一とくに Radio Isotope Lymphography を応用してー、リンバ学 6:248-252, 1983

14）小島 瑞, 山口昭彦, 土橋陸夫 : 網内系機能検查 法. 日臨 $26: 419-432,1968$

15）石榑秀勝：胃癌に沏けるリン八゙節転移々郭清に関 寸る臨床的, 実殹的研究. 名古屋医 $96: 10-23$, 1974

16）山田 肃：胃ソンバ系の検討一胃癌郭清術のため に一. 手術 $15: 138-148,1961$

17）川路高衛：胃のリンパ流と胃癌のリンパ節転移に 関する研究. 医研究 $53: 127-154,1983$

18）忽那将愛: 日本人のリンバ系解剖学. 東京, 金原出 版, 1968, p147-164 